\title{
What Do College Students Have to Learn from the Amish?
}

\author{
Caroline Brock ${ }^{1}$ \\ Department of Rural Sociology \\ University of Missouri-Columbia
}

\begin{abstract}
This paper presents the results of a survey of college courses taught on the Amish. It is based on a series of interviews with instructors at other institutions of higher learning whose courses focus on the Amish, an examination of their syllabi, and analysis of student writing from the course I teach at the University of Missouri-Columbia. The survey was designed to ascertain the goals of professors who teach a class about the Amish and how they best achieve their course objectives. Secondly, the survey explored what attracts college students to a course about the Amish, and what prior knowledge, and preconceptions they bring with them. My survey found that all professors relate themes and values about the Amish to the lives of college students, but there are subtle differences in how these connections are expressed by instructors in the classroom through various course activities. This paper should serve as a resource for people who want to incorporate information about the Amish in their college-level courses. ${ }^{2}$
\end{abstract}

\section{Keywords}

Amish, teaching, education, college courses, ethno-religious groups, Anabaptists 


\section{Introduction}

It seems strange and perhaps ironic to design college-level courses on a Christian minority who is opposed to education beyond the eighth grade. Yet many students are attracted to courses about the Amish. Amish faith and culture has informed college classrooms in a diverse range of disciplines and institutions of higher learning of every size, from small Mennonite colleges to large state universities (Loewen 2003).

This paper had its beginnings with a conference workshop at the Amish in America Conference in June 2013 (see http://www.etown.edu/centers/young-center/amish-conferencethurs-abstracts.aspx) where participants gathered to discuss teaching resources and methods for their classes that cover the Amish. This article was a follow-up and more channeled effort to gather insights from instructors who are currently teaching an Amish-centered class.

\section{Methods}

I began with those participants I met at the conference, and then employed snowball sampling to identify additional college-level instructors to participate in my survey. Semistructured interviews were conducted over the phone in July 2013 and the conversations were approximately 45 to 90 minutes in length. Syllabi from all participants were also collected and reviewed. The case study at the end of the paper focuses on my course, "Amish Community" (Rural Sociology 1150) at the University of Missouri-Columbia, which I taught during the spring 2013 term. It included a survey of students in the class as well as some analysis of student writing assignments. The study was approved by the Institutional Review Board (Human Subjects) at University of Missouri-Columbia.

\section{Findings}

\section{Teaching about the Amish in a College Course}

Amish courses are taught by professors from a wide range of academic backgrounds (Table 1). Although there was a significant fraction of courses which were offered by professors with backgrounds in sociology, rural sociology, and anthropology, there were also a number of courses in history and German. There were also courses offered by professors with backgrounds in English, Biblical, and religious studies, and economic geography. Some of the professors taught with a particular disciplinary background, but the class was listed under a different department than the professor's home department, which reflects the interdisciplinary nature of Amish studies. In fact, the interdisciplinary appeal of many Amish courses was one of its best assets, according to some professors. For example, Susan Trollinger actually takes advantage of this by asking the "students to study the writing of scholars from various disciplines and to try to notice the distinctive writing conventions of their discipline." She asks students to "consider what sort of evidence a biblical scholar like David Weaver Zercher" utilizes versus "the sort of 
Table 1: University Courses about the Amish: An Overview ${ }^{3}$

\begin{tabular}{lll} 
Instructor & Institution & Department/Academic Unit \\
\hline Anderson, Cory & The Ohio State University & Rural sociology \\
Brock, Caroline & University of Missouri & Rural sociology \\
Brown, Joshua & University of Wisconsin-Eau Claire & German \\
Dewalt, Mark & Withrop University & Education \\
Donnermeyer, Joseph & The Ohio State University & Rural sociology \\
Johnson-Weiner, Karen & State Univ. of New York-Potsdam & Anthropology \\
Kanagy, Conrad & Elizabethtown College & Sociology \& anthropology \\
Kraybill, Donald & Elizabethtown College & Sociology \\
Martin, Willard & Penn State University & German \\
McConnell, David & College of Wooster & Sociology and anthropology \\
Nolt, Steven & Goshen College & History \\
Reschly, Steven & Truman State University & History \\
Stevick, Richard & Messiah College & Psychology \\
Trollinger, Susan & University of Dayton & English \\
Weaver-Zercher, David & Messiah College & Biblical and religious studies \\
& & \\
Amish Focus for Part of a Class & Guilford College & Religion /campus ministry \\
Carter, Max & University of Wisconsin-Madison & German \\
Louden, Mark & Bluffton University & Communications \\
Mast, Gerald & Westminster College & Sociology \& criminal justice \\
Park, Kristin & Nelson Mandela Metropolitan & Economic geography \\
Webb, Nigel & University, South Africa & \\
\hline
\end{tabular}

evidence a sociologist like Donald Kraybill uses” versus “a historian like Steven Nolt.” She feels "it is all about getting [students] to be able to see that writing for one discourse community [discipline] is different in certain ways from writing for another.”

The courses generally focus on Old Order Amish rather than other kinds of Anabaptists. This trend of focusing on Old Order Amish is common in other academic studies as well as in the popular media. In this way, the other kinds of Amish, plus Mennonites and Hutterites, do not get covered as much. However, some of the classes made a point of covering other special religious groups. For example, Willard Martin and Mark Louden cover different kinds of Pennsylvania Dutch groups, so their scope is much broader.

As can be observed in Table 1, there is a diversity of courses offered focusing on the Amish. Although the courses listed here have been offered in the past six years, they are not necessarily taught either each semester or even annually. Pennsylvania has the most Amish scholars teaching courses related to the Amish, as 30\% of the courses are offered there, and Ohio is close behind with a quarter of the courses. Two courses are offered each in Wisconsin, 
Missouri, and North Carolina, so that $10 \%$ of the courses are offered in each of these states. Indiana, New York, and South Africa each have one course offering. While most college courses on the Amish have six to 30 students, Penn State has a course with about 90 students, while the University of Missouri at Columbia has two courses of 60 students every semester.

The states with the most Amish people are Ohio, Pennsylvania, Indiana, Wisconsin, New York, Michigan, and Missouri respectively (Donnermeyer, Anderson and Cooksey 2013). The student demand for Amish courses is likely elevated in states with higher Amish populations because students may be more curious and there may be practical reasons why it would be useful for many students to know something about Amish people who are their neighbors. However, the number of students taking Amish courses is not totally in line with this population distribution. For example, Indiana has the third highest Amish population of any state in the United States, yet Steven Nolt teaches the only course offered by a university in the Hoosier state, and even then, he has not taught it for a few years.

One may wonder why there are not more courses that address the Amish at Mennonite and Brethren colleges, which could increase course offerings even more in states like Indiana, Ohio, Pennsylvania, and Virginia. Although this paper cannot address this question directly, Gerald Mast at Bluffton University offered an idea that may shed some light on the issue. He stated:

...some Mennonite colleges (like Bluffton) have taught Amish history and culture typically as part of their mission to teach Mennonite students about their faith and heritage; hence Amish studies is embedded in Mennonite studies for the most part at Mennonite colleges.

In this way, Amish Studies may be embedded in a larger class about Mennonites, such as in the "Mennonite History and Thought" class at Bluffton or the class titled "History of Mennonites in America” offered by Steven Nolt at Goshen College. However, Mast further explains, as Mennonite colleges seek to expand their "student bodies beyond Mennonite students, it probably seems counterintuitive to expand into Amish studies” as this may not fit into the agenda of nonMennonite students. Mennonite colleges have historical libraries and journals which further the pursuit of knowledge of Anabaptist-Mennonite history and theology. However, the relationship of the Mennonites to their own distinct Mennonite background is evolving (Brandt 1994). In addition, Mennonites who live around the Amish and/or who have direct personal experience with the Amish faith and/or connections to ex-Amish people may have a more critical view of the Amish because of their own negative experiences. For example, some of the students may have parents or grandparents who were Amish at one time.

A number of the instructors who teach a course on the Amish have some kind of Mennonite connection, even at the secular schools. Their backgrounds ranged from plain Anabaptist connections (e.g. ex-Old Order Mennonites and a practicing Beachy Amish- 
Mennonite), to several who grew up in progressive Mennonite church communities and continue to be affiliated with such churches. Plus, there are two professors who joined Mennonite Church USA congregations as adults. One professor was reared by a grandmother who spoke Pennsylvania Dutch. A few of the professors do not have a religious or ethnic connection to the Amish but came to them primarily in the role of an academic researcher.

Student Motivation and Demand: In general, professors feel that there is significant student demand for Amish courses, citing courses which have a waiting list to get into them. There may be institutional barriers that make it difficult to offer more Amish-centered courses. Some departments have numerous demands on faculty time and student degree requirements, and it is often not clear where the Amish course would fit into faculty schedules and student degree programs.

There are also advantages to keeping the courses that are currently offered at a smaller size. For example, Mark Louden used to teach a class at University of Texas-Austin which had 100 students. He felt that the size was too unwieldy, especially since a major goal of the class was to dispel individual students' misconceptions about the Amish. Thus, he feels more comfortable with the smaller sizes of his classes at the University of Wisconsin-Madison. Other professors like Donald Kraybill have writing intensive courses where a lot of personal attention is required, so it would be difficult to offer this kind of course to a larger group.

Some of the courses fulfill requirements which integrate them into the curriculum as a regular offering. For example, the Amish course at the University of Missouri-Columbia fulfills a needed humanities requirement for students in the College of Agriculture, and it also fulfills a writing intensive requirement. A few other courses also fulfill writing and research requirements, although some of the others were more specialized honors courses. However, many of the Amish-centered courses merely fulfill an elective, so requirements are not always a relevant draw for students.

There are some students who have very practical reasons to know about the faith and culture of the Amish. Joshua Brown at University of Wisconsin-Eau Claire teaches an online Amish course which includes a large share of nursing students who will likely have Amish patients in their future careers. Likewise, the agriculture majors taking the Amish course at Penn State may be working with Amish farmers sometime in the future. Such cultural competency has been helpful in working with other conservative Anabaptist groups, like the Hutterites, in the medical arena (Fahrenwald, et al. 2001).

Many of the students are motivated to learn about the Amish for general background because they were exposed to Amish people, at least to a limited degree, before their college years. For example, Amish buggies use a public road that transverse the College of Wooster's campus in Ohio. Amish communities are located nearby most of the other colleges and universities found in Table 1. Further, even if the students were not exposed to the Amish in real 
life, the majority of my students have certainly watched a lot of the Amish reality shows and some may have read Amish romance novels.

Quite a few professors said their students are disproportionately female. The reasons why females are more drawn to courses on the Amish would be an interesting topic for further research. David Weaver-Zercher conjectures that the popularity of Amish romance novels may be one draw for female students. There are probably larger issues that attract a disproportionate share of women to a course about the Amish, such as their tendency to focus more on social relationships, with the Amish representing a culture where relationships are primary.

Goals of Professors: The larger goals of professors for teaching an Amish course are varied. The Amish can illustrate how social structures influence subcultures. The symbols of Amish society can be used to understand the Amish within community structures, institutional arrangements, religious contexts, and historical contexts. A couple of the professors feel that the Amish are helpful for exploring the concept of modernity. Donald Kraybill's Riddle of Amish Culture (2001) prods readers to think about modernity in a different way than the conventional approach. After all, if modernity is about making choices, the Amish certainly have made more collectively conscience choices about technology use than many non-Amish. Some professors like the concept of "boundaries" to define a theoretical framework and how the Amish carefully limit connections with the outside to ensure they maintain their faith and culture. For some professors like David Weaver-Zercher, the perspectives outsiders hold about the Amish are an important component of the course. David McConnell stated that the theme of diversity and change within the Amish is so important that by the end of the semester, his students are weary of these themes because he hits them so hard. A few professors' primary goal is to teach writing and research in addition to learning something substantive about the Amish. For example, Donald Kraybill emphasizes learning how to use and interpret primary resources.

Some of the professors have a goal to counter misconceptions amongst students about the Amish; hence, it is important to meet the students where they are at in terms of what they bring into the course. A number of the professors like to find out what ideas about the Amish the students bring with them. In a survey of my class, I found that the top four words/phrases that came to the students' minds on the first day of class when they think about the Amish were farming, horse and buggy, dress, Christianity/faith, and no electricity. Christianity and faith were among the most commonly mentioned words, but the fact that these words were further down the list was not surprising considering the outsider's tendency to focus on dress and appearance rather than the reasons behind them. Students came with varied misconceptions about the Amish. The misconception of the Amish as technophobes or frozen in time was mentioned by a number of professors. Amish reality shows like Breaking Amish also contributed to a sensationalized view of Rumspringa where the Amish are supposed to go wild during this period. Another common misconception is that the Amish do not pay taxes (Kraybill, Johnson-Weiner and Nolt 2013). Students sometimes accuse the Amish of being hypocritical because they perceive that they do not follow the intent of the rules that they set out. For example, some students may think 
it is hypocritical that they ride in cars but do not drive them. As one professor stated, the students tend to think that their assessments of hypocrisy are brilliant insights. This is more common among Mennonite students and/or students who grew up near the Amish. This assessment of hypocrisy can be a challenging one to counter by professors, though understanding more of the background beyond the rules can be helpful.

Some students came with an interest in the Amish as a model for better living, as was the case with students at Guilford College, a Quaker school. Max Carter stated that some students have the impression that the Amish are all about social justice and organic food and then are shocked and disillusioned when they discover that Amish shop at Wal-Mart. There are also some negative impressions that the Amish all marry their cousins and that there are genetic problems, considering they are a small isolated population. Mark Louden shared a particularly interesting way to counteract stereotypes of the Amish as an endogamous society where "in-breeding" is a serious problem. He draws a parallel between the population size of the Amish and the population of Iceland, which are roughly comparable. A recent study showed that the highest fertility rates in Iceland are among couples who are third cousins, that is, between partners who are neither closely nor distantly related to one another (Helgason, et al. 2008).

Resources of Professors: Many of the professors are using similar textbooks for their classes, but there was more diversity than expected considering there are not a lot of standard books about the Amish (see Appendix 1). Fifty seven percent of the solely Amish-centered courses use Riddle of Amish Culture (eight out of 14), and the next most popular book was Growing up Amish (four of 14). Next were Amish Paradox, Amish Grace, and Rosanna of the Amish each used in three instances. Two professors are considering Growing Up Amish after experimenting with it; they like how the book centers on a personal story, and they like the realistic back-and-forth decision making that the author had about being Amish or not. Some of the professors are considering transitioning from the Riddle of Amish Culture to The Amish now that it has been released. A number of professors talked about the importance of primary sources like 1,001 Questions about the Christian Life, In Meiner Jugend, Family Life, and the Budget, all written by Amish authors.

Cory Anderson is teaching his first class as an instructor during the autumn 2013 semester and has not adopted a standard textbook. Instead, he draws on journal article and book chapter readings, supplementing academic texts with an Amish-authored book, Daniel Miller's At Home in Hickory Hollow, a compilation of 29 short stories about everyday Amish life. Some other professors also refer to websites like etown.edu/amishstudies/Amish_Publications.asp.

Professors were asked about what they would recommend to other professors who may teach an Amish course in the future. One professor emphasized the faith-based aspect of Amish life and how the Amish people are successfully growing in numbers in the United States compared to mainline Christian dominations. It is also important that the students are exposed to a diversity of perspectives on the Amish people and have a sense of humor about the discussion. 
Donald Kraybill stated that instructors should focus on what motivates students rather than being comprehensive. Steven Nolt said that each professor should teach to their strengths and passions. This insight is fitting given the wide range of backgrounds of those teaching Amish courses.

Professors had a variety of creative learning activities to offer when asked about highly successful classroom activities. Most professors stated that a field trip was the most successful and impactful course activity. Cory Anderson discussed how, when he guest lectured in introductory rural sociology courses, he would map out the social networks and connections of a typical Amish person and compared these connections with what is typical for students in the class. He also connected with the students by asking them why the Amish like volleyball and how it illustrates their preference for equality, teamwork, and modesty. Steven Reschly's favorite activity in his history course is to have the students follow a community in the Budget for a year; he finds that to be a great learning experience.

David McConnell has the class analyze copies of the local Ohio Amish Directory and "put their anthropologist hats on" to see what they learn about the community and families through closely reading the Mark Dewalt created a role playing exercise with scripts he wrote so the students could simulate an Amish classroom. He said the students really enjoy this. A simulated classroom was created for younger students preparing for an actual trip to an Amish school in another context (Morris 2003). Joseph Donnermeyer gives an “Amish IQ test” at both the beginning and end of the course so students can see what they have learned. As a writing assignment, Donnermeyer gives students hypothetical situations where they have a relative who has negative misconceptions about the Amish and they need to write about how they might persuade this prejudiced relative to see the Amish in a different and more educated light. In Joshua Brown's online class, he finds that the students can have frank and insightful dialogues by requiring them to post about a certain topic and respond to other students' posts. Donald Kraybill thinks that giving his students ownership on researching a certain topic and having teams debate it in the class is most helpful for the students. He also finds that presenting a final research paper to the class as well as to a larger public audience is a good way to motivate the students to apply themselves.

A number of professors discussed the importance of using visuals and videos like The Amish, Devil's Playground, Amish Grace, and Witness (see Appendix). David McConnell preps the students for watching Devil's Playground so much so that in his opinion they are really able to dig into it by the time they watch it and realize that it depicts an extreme form of Rumspringa. Susan Trollinger finds that showing students Amish Grace-a movie about the Nickel Mines tragedy - makes the students react in a very emotional way. She then has them respond to a writing prompt in class and talk about their written responses. That gives them a chance to think about what they have seen and what they are feeling before they try to articulate something to the group. She makes sure to do this unit at the end of the semester when they know one another quite well. Joseph Donnermeyer and others mentioned the importance of guest lecturers and how they can help the class engage with the material. Guest lecturers who are Amish may be the 
second best thing to field trips.

Field Trips in Amish Classes: A few of the classes offer field trips, either as a required part of the class or as an option. As one professor stated, "the field trip is by far the most important thing that they do all semester, they can't anticipate it and they are just not as prepared as they thought they were going to be.” There are a variety of destinations on these field trips including produce auctions, scratch and dent stores, Amish-owned businesses, visits with Amish leaders, Amish historical societies, and schools. Those professors who have a field trip say it is the most important thing that they do. The timing of the field trip in the semester is important. Some professors say that it is best to do it at the beginning so that they can use the personal experience to engage with the material throughout the class. Others think it is appropriate at the end when the students are more prepared to make observations in context. One professor thought the field trip was best in the middle of the course so they could balance the two approaches. Mark Dewalt and Max Carter both visit a community in North Carolina, and Carter stated that it is "bar none the best activity" in the class.

The most intensive and involved field trip was the home stay arranged by Richard Stevick of Messiah College. Stevick exclaimed that the field trip was the most joyous part of his career in the last 20 years. One student gives an account of some of her experiences with the family stay in a witty blog post. Her statement "Overwhelmingly, the biggest lesson I learned ... is that the Amish are real people too, and in their humanity, they are much more similar to me than I ever thought” (Bean 2011). Her blog gives a picture of how some of the students develop long-lasting friendships with their Amish host families. For example, one of the Amish host families was at a former student's weddings. A lesson many students take away from their experience is a deep respect for the Amish faith. This respect for their faith is remarkable because at the beginning of the class, some students questioned whether or not the Amish were truly Christian.

Not all professors are fortunate to have the geographic proximity and the contacts to make field trips happen. It can also be logistically impossible with larger classes, and institutional red tape can make it challenging to arrange the field trip. Stevick's family stays are very labor intensive, and building relationships with the Amish can take time. Stevick inherited the class from another professor who already had established many Amish contacts, which meant he was able to "gain instant access and credibility." He said the following:

However, getting 36 families - 18 in Lancaster County and 18 in Ohio-is a very timeconsuming task. That is one reason why I limit the course size to 18 if I have an assistant and to nine or ten if I teach it alone: getting families is very labor intensive. Having said that, I and the students have found those contacts to be both enjoyable and important for gaining insight into the Amish way of living and thinking. One can teach a credible course without home stays, but home stays provide a richness that cannot be attained any other way. 
Other professors, like Max Carter, did not have to struggle much making contacts. He thinks it helps being a Quaker, as he stated that the Amish are respectively curious about Quakers. It also helps if the professor is near an Amish community that is more open. The Union Grove, North Carolina, community has quite a few converts, which is unusual for the Amish, and they are much more open to talking to outsiders than typical Amish communities. Kristin Park previously organized field trips, but she says it is uncomfortable bringing a group of 20-plus students into an Amish community. She is currently thinking it would be more appropriate to encourage the students to make trips as individuals. She stated, "[I] currently encourage students to visit Amish shops (e.g. a greenhouse, quilt shop) individually or in small groups so as to have what I consider more respectful interaction with members of the community.” Steven Nolt also talked about how it was challenging to arrange multiple trips in one day to accommodate his many students.

Connecting with the Students: Most professors attempt to help students connect material about the Amish to their personal lives. However, the method and philosophy behind these connections are varied and controversial in subtle ways. For example, some of the students come with a strong notion of Amish lifestyles as inconsistent, contradictory, and even hypocritical. However, Susan Trollinger stated that students can struggle to identify contradictions in their own culture and that "helping them both see and understand the 'contradictions' in Amish culture and where they come from helps them, with a lot of effort, to see some analogies in their own culture.” For example, though the mainstream college culture seems to value individualism, if one takes a look around and sees the clothing and hair styles of college students, one might not think there is a lot of individual expression. I had the same challenge of trying to get the students to see the riddles in mainstream society. Donald Kraybill offered some helpful advice about being provocative to get students to think about the social rules (Ordnung) that they follow in the classroom. He asks the students questions like, "Who has the power in the classroom? Why are you sitting quietly? Why do you sit on the same seats each time? Why do you raise your hand when you want to talk? Why are you not picking your nose, etc.?” I got the sense if enough questions were posed to the students about their behavior in the "here and now," it may help students think about their own culture in a more critical light.

Joshua Brown talked about how some of the dialogue in the classroom gets into heated debate, especially from those students who romanticize the Amish lifestyle. However, Brown would prefer that student not romanticize the Amish. Holding onto negative stereotypes and romantically positioning the Amish as better both serve to de-humanize them, in his opinion. He wants his students to have a critical view of the Amish as well as our own culture. He would prefer to have students learn more about themselves by learning about the Amish. For example, the Amish use symbols in their society, but so do we. It is important for students to realize that they are as embedded in social structures as much as the Amish, and there are symbols for the culture in which they are embedded as well. David McConnell says students come into the class "thinking that the Amish are a world apart” from them, but there are so many learning 
opportunities in which students can learn ways to connect their lives with Amish lifestyles.

Rumspringa is one of those opportunities for making connections. David McConnell shared stories with his class about having children the same age as those in the movie, and the challenges with parenting during teenage years are not that different from those faced by Amish parents. The connection with Rumspringa and the lives of college students may be a reason that Devil's Playground and Growing up Amish are such popular books.

Professors have varied opinions about the extent to which they should connect the Amish with the students' lives directly. For historians like Steven Reschly, this might be considered "presentist," a problem in history in which present day ideas impact the interpretations of the past too much. Reschly also finds it problematic to extract out principles from the Amish and try to implement them into our lives. For example, trying to take a virtue like forgiveness without the support system of the Amish, he thinks, is just not going to work.

Cory Anderson stated that he feels the mainstream Anabaptists, who have written some of the major writings about the Amish, moralize the Amish in a way that ends up reading like their own religious positions. He does not want to moralize the Amish to the class, given his obvious bias from having joined a plain group, the Beachy Amish-Mennonites. He does acknowledge students take away lessons that can be helpful for their own lives. A student evaluation of one of his guest lectures indicated how Anderson’s non-judgmental comparisons of Amish and mainstream society led a student to want to "adopt some of [the Amish] beliefs and apply them to [her] own lifestyle.” Although this student did not indicate what Amish principles they may apply to their life, it is clear Anderson's approach to teaching about the Amish can lead to transformative and applied reflections.

Joshua Brown is also careful about taking any kind of evaluative stance about Amish principles with regards to student's own lives. He finds it problematic when students become critical about their own technology use, such as their cell phones, based on their observations of the Amish. He also feels that students see Amish lifestyles as a way out of the stresses in their daily lives. Their slower pace of life with more restricted use of technology may seem less demanding or stressful then their own busy college schedules. Joseph Donnermeyer asks students to consider lessons they may learn as a two-way street. What lessons can the Amish teach the English, and what lessons can the English teach the Amish?

Mark Louden is cautious about encouraging students to connect Amish principles with their own lives because he wants to ensure that they are well grounded in their knowledge of Amish people. He stated it is more of a priority to get the students to engage with rigorous research on the Amish, otherwise they will rely too much on their own subjective opinions and impressions. However, he feels that the most important thing to convey about the Amish is that their Christian faith is at the very center of their life and culture, which may or may not resonate with students' personal lives. 
Other professors more directly connect students' lives with Amish values and principles through discussions and assignments. As discussed earlier, Richard Stevick's class at Messiah College involves home stays and intensive journaling, which inspires personal reflections about Amish lifestyle. David Weaver-Zercher has the students write and think about the spiritual dimensions of the Amish people, and given the Christian faith background of many of the Messiah students, this is likely to have a personal impact.

Max Carter from Guilford College connects Amish values with student lifestyles in his classes in a more tangible way than many of the other professors. The Amish are discussed in a critical way, but the values of community and simplicity are major themes in his classes. Carter stated that his field trip is really engaging for the students, as they often find that the Amish are radically different from their circumstances, and some of them wonder about how "can I incorporate some of this into my own lifestyle?” One student was so inspired by the field trip that she went back to her dorm after the field trip with the intent to simplify. She looked around at all of her stuff in her room to see what she could get rid of there. She was so overwhelmed when she realized how challenging it would be, so she threw up her hands and went out clubbing. In contrast, Carter had a couple of students who decided to become Amish after his class, which is amazing considering there are very few converts to the Amish faith (Kraybill 2001). Carter was the only professor who had some students who connected with the Amish and their own life in such an intimate way that they converted to the Amish faith. Although the two former students did not stay within the Amish church, the fact that they tried to pursue this lifestyle was quite remarkable.

\section{Personal Insights from Student Writing in a University of Missouri-Columbia Class}

After this overview of the different Amish-centered courses, I will look more in depth at my class as a case study. A frequent question that I get about my new teaching assignment at the University of Missouri-Columbia goes something like this: "You are teaching a class called 'The Amish Community’ AND you may have 120 students taking it next semester!?”

The class is housed in the agricultural school. It was originally taught by a dynamic professor who liked to tell stories and had a mother who was Old Order Mennonite. In this way, the University of Missouri class resembles the class at Penn State, as it is also a larger class which had been taught by someone who is good at telling stories and who had Old Order Mennonite connections. The class at Penn State also has a lot of agricultural majors, though it is housed in the German department.

The Amish class at the University of Missouri emphasizes Amish values at length and the social, religious, and historical context in which they are embedded. There are different ways that I compare and contrast with mainstream society and the sub-cultures within which the college students are embedded. For the student's first writing assignment in the class, students are asked to consider an organization that they participate in and the basic premise/values of the 
organization and how the rules and rituals of the organization reflects these premises and values. They then compare these organizations with the Amish and what might be learned from the Amish. This assignment gives them a chance to think about what their organizations really value and how that plays out in the rules and rituals that they follow. This may be the first time that students have reflected on these issues. One student discussed her involvement at a relatively conservative Protestant church. The student stated that there is the focus on "the individual" which "left many at her church wanting a stronger community." There is a stronger community emphasis within the Amish. She stated that there needed to be more incentives for attendance so that a more intimate community could be developed at her church.

In addition to discussing churches, a fair number of students talk about their sororities and fraternities. One student described her sorority as valuing "hard work, sincerity, honesty, community, and many other values." She felt that the sorority could have a greater sense of modesty, which is a value that the Amish regard highly. She believes that for some pride can be a good thing but sometimes it can lead to "making another person feel inferior." She would rather see her fellow sorority mates "boast about the accomplishments [of] others." This is probably not how the Amish would view humility, but she was able to think about how this value would apply in her sorority's context. Another student writes about her softball team, and one value she felt that the team could learn is the concept of gentle and humble leadership. She felt that her softball coach was a "scary leader who used fear to gain success." This student had read about the gentle bishop in Rosanna. The ideal of gentility and humility in churches is certainly revered among the Amish.

It was also enlightening to see some of the students from different religious and cultural backgrounds connect with some of the values and rules of the Amish. One woman observed how the Islamic faith and culture, like the Amish, emphasizes modesty in clothing, especially for females. She discussed the school dress code in her home country as to how the faith is lived out. She stated that,

We had to be covered from head to toe whenever we had to leave the school. We were not allowed to pass the gate without covering ourselves with an extra piece of clothing called Abaya. It had to be baggy, loose, non-transparent, and doesn't contain exaggerated decoration like extra glitter. This is one of the values of an Islamic school and their roles would be being strict and punitive if any girl goes against it.

She connected with how religion influenced the teaching of different subject matters within the Amish and of her own experiences. It would have been enlightening to have her flesh out in more detail how the exact values and rules would have contrasted with the Amish.

In the class, we discuss how the students may extract Amish principles and apply these values to their lives. Outsiders often do not have an accurate reading on how precisely these values are really thought about and carried out within the Amish, much less the complexities of 
applying these values to an English lifestyle. However, it is nevertheless compelling to think about one's own values through a model like the Amish. Outsiders' views of the Amish have a powerful influence on how the Amish are interpreted (Weaver-Zercher 2001). The students read a short excerpt from Almost Amish as an example of how some English folks have tried to adopt elements of the Amish lifestyle in their own life (Sleeth 2012). Nancy Sleeth and her family transform their mainstream suburban lifestyle to a much simpler lifestyle that they felt was more spiritually fulfilling as Christians. These kinds of stories can challenge students to think about their own values which can be powerful experiences, even if the details are not precise and not truly and authentically “Amish.” This book is about ten lessons we can take from the Amish. However, the four lessons that the students connected with the most were: (1) saving more and spending less; (2) technology should serve as a tool not a master; (3) family ties are important; and (4) spending time in God's creation.

The students are given a lot of opportunity to reflect on Amish values as presented in books like Riddle of Amish Culture and Amish Way. They think about how they might design rules to preserve these values / principles that they would like to work on in their own lives. In contrast to Joshua Brown's concern with having the students critique their own use of technology with regards to the Amish, students are encouraged to think about the Amish views on technology and how they might think differently about technology in their own lives after observing the Amish. For example, as indicated above, many of the students would like to work on having technology serve as a tool rather than a master. Many of the students realize that they suffer from "nomophobia” (nomophobia.com) or addiction to their cell phones such that they are afraid to be disconnected or out of touch with their friends for very long. Many of my students cannot go an hour without checking their phones even if they know that their participation grade will be negatively impacted by their behavior. These students are often aware that their cell phone is more than a tool, becoming a master of their lives and inhibiting their ability to communicate and connect in person. At the same time, the students realize that they need the cell phone as a tool to connect with their friends and family. In a class exercise, some of the students design cell phones and rules which would be more fitting to preserve "Amish style values." It is interesting that a few students come up with cell phone designs that are similar to what is advertised to the Amish people, such as cell phones which are pay as you go and are not able to connect to the Internet.

The class discusses different values that the Amish emphasize in more detail in distinct lessons. For example, we discuss the concept of forgiveness by reading sections of Amish Grace and the movie documentary The Power of Forgiveness, which addresses Amish forgiveness in response to the Nickel Mines shooting. We also look at other individual models of forgiveness which have similar values but differ in philosophy and religion from the Amish. We compare that case with the ideas about forgiveness from well known Holocaust survivor, Elie Wiesel. He has a stronger sense of justice and desire for a public apology to right the wrongs of the horrors of the Holocaust. Whereas for the Amish, forgiveness was more independent of apologies and bringing 
the culpable individuals to justice.

We also discuss the research of scholars like Everett Worthington, who examines the concept of forgiveness amongst college students who are from the "millennial” generation (Doblmeier 2008). In the documentary, Worthington discusses how college students are challenged with the concept of forgiveness on a national/global scale as well as their personal lives. He discusses how most college students were reared post-9/11 within a culture more focused on retaliation. He has counseling sessions that involve role playing, helping college students consider forgiveness at a deeper level in their lives.

In addition to discussing different approaches to forgiveness, the class compared and contrasted Anabaptist pacifism to versions of a "Just War." The students were asked: "What does your faith community or other important influences on your life say about war?” For the most part, the students struggled articulating at any length what their faith tradition and background stated about war, as most churches and organizations do not discuss this directly.

One Catholic student who seemed quite grounded in her faith stated that the "Just War doctrine is not a heavily taught from or talked about part of the church.” Some of the student essays speak to this retaliation/justice seeking sub-culture that Worthington discusses. One student described how the "Catholic faith teaches us that we are all God's children and that we must love one another because we are all gifts from God.” However, she also was aware of the influence of nationalism, as she stated, "I also grew up in the years directly proceeding 9/11, so the messages of my school, my community, and my country have generally been very supportive of war as a means of justice.” The class writing exercise may have helped this student further flesh out that the church was not the main influence on her life when it came to her views on war.

Another student from a conservative branch of a mainline Protestant denomination illustrated how nationalism has been blended with his branch of Christianity. He stated that "We, as Christians and as Americans, are charged with upholding Christian values, and with defending the freedom to live out those values." This student stated the goal of war is to "stop the enemy from encroaching upon the way of life that has been described as 'inalienable' and 'endowed by our Creator." ' He expressed that "while the Amish church teaches that violence is wrong in any form and for any reason, my faith realizes that we live in an imperfect world and that sometimes, armed conflict is the only method of preventing our religious freedoms from being lost.” These quotations showed how students can compare and contrast their views with the Amish and can express their clear paths of departure in values.

A student who was part of the armed services compared the Amish stance on nonviolence and forgiveness with military values. Although he acknowledged that "the armed services cannot adopt the Amish stance on total non-violence and continue to function as a productive branch of the U.S. military, [the armed services could] gain much from observing the pursuit of this stance." He felt that "one organizational flaw" of the armed services "may be that 
violence is used too quickly as a solution to the problems it encounters." He stated that progress has been made in this direction in the armed services, but there is still room for improvement. As he compared Nickel Mines to September 11, 2001, he described how the "the Amish immediately put into action an impressive commitment to forgive.” In contrast, "the Armed Forces and the U.S. as a whole displayed an earnest desire for justice.” He emphasized that it is not clear which response, the Amish or the armed forces, is the correct one, and perhaps their responses should not be the same, but careful consideration is important. He wondered, "Who would defend the Amish right to practice their way of life freely, if not for military personnel who assume a nearly polar opposite approach to violence when compared to the Amish?” Likewise, if it were not for the Amish, "Who would question the methods of such military personnel and keep them in check without the concept of unconditional forgiveness being presented by groups such as the Amish church?” He felt that these questions presented "quite a paradox, and likely have no definitive answer.” He offered a provocative challenge of ongoing discussion which could "continue to prod the social consciousness and decision-making processes that are required for civilization as a whole to advance beyond its current condition." This was one of the most thought-provoking pieces of student writing and it illustrates the possibilities of critical thinking that can happen when comparing and contrasting student lives with that of depictions of the Amish.

\section{Growing Up English and Amish}

The students have a paper where they reflect on their primary, high school, and college time periods and do some comparing and contrasting with the upbringing of the Amish people. The students read the Amish newsletter, Blackboard Bulletin, as well as the chapter in Growing Up Amish about Amish schools. Many of the students discuss how competition is emphasized so much more than cooperation in English schools in contrast to Amish schools. As one student stated, "my peers always seem[ed] to be comparing grades or boasting about how well they did on an exam or paper." She contrasted with what she read about in Blackboard Bulletin, where the "Amish students actually help each other with their class work." The lack of science education and the importance of faith in religion were mentioned by some students. Although for some students, the emphasis on faith and devotions was also part of their experience, as some went to Catholic and Lutheran private grade schools.

The high school and college reflections were especially engaging considering the age of most college students. As the students were reading about Amish young people, I also had them learn about themselves by reading College Eyes through the Eyes of the Students by Mary Grigsby (2009), a colleague in my department. The students see a preview of National Lampoon's Van Wilder (2002) and they can make comparisons on how college culture is sensationalized by the media just as Amish Rumspringa is also sensationalized. As one student stated, in most any film about college life, you will see a view depicted as a "time to party, drink, and have frivolous relationships.” This student explains that in these films, "women are often viewed as objects that are only there for sexual pleasure and men are portrayed as lazy frat boys 
who like to drink.”

The students also learn about the diversity of college students and can connect to the diversity of how Rumspringa may be experienced. According to Grigsby (2009), college students can be classified into a variety of types, including collegiate, careerist, academic, and alternative. Students were able to identify with at least one of these types, especially the collegiate category because interaction with peers is often cited as a key reason why students attend college (Grigsby 2009).

The transition from a family-centered life to a more peer-centered life which characterizes the Rumspringa time for most Amish young people is also true for the high school and college period for English young people (Stevick 2007). One student equated her high school experience more with the Amish as her focus shifted from being primarily "family and the church as a whole” to her peers, and she "hung out with them as much as possible." She devoted more time to activities which "fit perfectly towards [her] dreams of college." The Amish do not have these same goals but they may have "many dreams of their own from marrying someone to owning a business or working alongside their family and joining the church.”

On rare occasions, Rumspringa for young people may be a period with few rules from parents, as some of the students describe their college time period. Some of the students experience a huge period of independence since "it was my first time living on my own, without any rules or money from my parents.” One student described moving away from home and experiencing "new ways of thinking and learn[ing] a lot from other people. Doing this allowed me to try new things and to learn more about the world and people in general."

We discuss ex-Amish towards the end of the course and what factors can lead the Amish away from the church. We learn how questioning the fundamentals of the Amish way of life with a Christian framework can lead them to question their faith and possibly leave the Amish church. We discussed the documentaries Trouble in Amish Paradise and Questioning Amish Paradise that describes the influence of groups like the Charity Christian Fellowship, which offers an articulate path to salvation and a more personal view on faith. Although the main characters in those documentaries are beyond the typical Rumspringa age, they underwent a deep period of questioning. One student who came from an Islamic country had a period of discovery through high school which led her away from the mosque. A period of questioning may lead other people from more conservative churches like the Amish away from their faith.

"My high school experience was full of exploring. This phase of my life was basically a phase that introduced me to many ideas, values, and conventions. I started to question all those belie[fs] that the community and family told us in the name of [G]od. Was [it] really from [G]od or was it something extra?”

This student was questioning if the rules that she had been abiding by all her life were really ordained by God or were they human-made rules that were not really critical for a life of faith. 
The readings, writing assignments, and class activities are designed to encourage students to compare and contrast their lives with the Amish. This can help students to critically reflect on their own lives as well as reflect and consider Amish values. Though it is important that these values are considered in the broader context of the Amish faith and culture, and indeed, there are many limitations on indiscriminate applications of who the Amish are to our own cultural values and way of life, students can be challenged to think differently if given the opportunity to consider a distinctive group like the Amish.

\section{Concluding Remarks}

More research is needed on collegiate-level teaching about the Amish and other plain Anabaptist groups. There are many instances where the Amish are used as examples in textbooks in areas like technology (e.g. Rogers 2003 and Kelly 2010). One of the most successful lessons in my "science and technology" class is using the Amish as an example of how faith and values inform how people choose to adopt technology. Demographers use the Hutterites when looking at fertility and conservative Anabaptists are used broadly in the medical arena because of their isolated gene pools. Further study could construct a picture of how and where the Amish are utilized and could be applied to the implementation of new courses and the revisions of established courses. This would help navigate what aspect and what part of that history and theology should be emphasized at both private, religious institutions, and secular universities (Loewen 2003). In conclusion, I hope that this article will help foster a conversation that will improve the classes of those already teaching about the Amish, as well as those who are considering teaching about the Amish. Hopefully, there will be a widening base of knowledge in teaching about the Amish in the college classroom as time goes by. ${ }^{4}$

\section{Endnotes}

${ }^{1}$ Contact information: Caroline Brock, Rural Sociology, Gentry Hall \#230, University of Missouri, Columbia, MO 65211 brockcc@missouri.edu; 5738843725

${ }^{2}$ I want to thank the professors who shared their experiences and expertise on teaching about the Amish in a college setting. I am also grateful to The University of Missouri for giving me the opportunity to teach a large class on the Amish and to my students by their willingness to share their writing assignments. Bret Myers provided invaluable editorial assistance.

${ }^{3}$ All professors were interviewed except for Karen Johnson-Weiner, Conrad Kanagy, and Nigel Webb.

${ }^{4}$ Please contact me if you know of someone else who may be teaching a class about the Amish. I would welcome comments and thoughts from plain Anabaptists readers who may have insights on what topics would be most important for college students to know about their faith and culture. Readers are encouraged to contribute to the base of knowledge. My next step will be to create a resource webpage about teaching Amish courses. 


\section{References}

Bean, Susanna. 2011. “Amish Cross-Cultural.” Accessed October 11, 2013 (http://susannabean.wordpress.com/category/amish-cross-cultural).

Brandt, Steven. 1994. “The Teaching of Anabaptist-Mennonite Studies in American Mennonite Brethren Colleges.” Direction Mennonite Brethren Forum 23(2):98-106.

Donnermeyer, Joseph, Cory Anderson, and Elizabeth Cooksey. 2013. "The Amish Population: County Estimates and Settlement Patterns.” Journal of Amish and Plain Anabaptist Studies 1(1):72-109.

Fahrenwald, N.L., R. Boysen, C. Fischer, and R. Maurer. 2001. "Developing Cultural Competence in the Baccalaureate Nursing Student: A Population-Based Project with the Hutterites.” Journal of Transcultural Nursing 12(1):48-55.

Grigsby, Mary. 2009. College Life through the Eyes of Students. Albany, NY: State University of New York.

Helgason, Agnar , Pálsson Snæbjörn, Daníel F. Guðbjartsson, pórður Kristjánsson, and Kári Stefánsson. 2008. "An Association between the Kinship and Fertility of Human Couples.” Science 319(5864):813-16.

Kelly, Kevin. 2010. What Technology Wants. New York: Penguin.

Kraybill, Donald. 2001. The Riddle of Amish Culture. Baltimore, MD: Johns Hopkins University Press.

Kraybill, Donald, Karen Johnson-Weiner, and Steven Nolt. 2013. The Amish. Baltimore, MD: Johns Hopkins University Press.

Loewen, Harry. 2003. “Reflections on Mennonite Studies at a Secular University.” Journal of Mennonite Studies 21(1):13-26.

Morris, Ronald V. 2003. "Sharing a Cross Cultural Exchange in an Amish World.” Canadian Social Studies 38(1). Accessed July 25, 2013 (http://www.educ.ualberta.ca/ css/Css_38_1/ARsharing_culture_amish.htm).

Rogers, Everett. 2003. Diffusion of Innovations. New York: Free Press.

Sleeth, Nancy. 2012. Almost Amish: One Woman's Quest for a Slower, Simpler More Sustainable Lifestyle. Carol Stream, IL: Tyndale House Publishers.

Weaver-Zercher, David L. 2001. The Amish in the American Imagination. Baltimore, MD: Johns Hopkins University Press. 


\section{Appendix 1: Books and Media Used by Instructors of Amish Courses}

\section{Primary Sources}

1001 Questions and Answers on the Christian Life. Aylmer, ON: Pathway Publishers.

The Budget. Sugarcreek, OH.

Blackboard Bulletin. Aylmer, ON: Pathway Publishers.

Family Life. Aylmer, ON: Pathway Publishers.

\section{Secondary Sources}

Champion, Gregg. 2010. “Amish Grace.” in Amish Grace. Twentieth Century Fox Home Entertainment.

Doblmeier, Martin 2008. The Power of Forgiveness. Journey Films.

Graham, Ludo. 2007. Trouble in Amish Paradise. British Broadcasting Corporation (BBC).

Hurst, Charles E., and David L. McConnell. 2010. An Amish Paradox: Diversity and Change in the World's Largest Amish Community. Baltimore, MD: Johns Hopkins University Press.

Kraybill, Donald B., Steven M. Nolt, and David Weaver-Zercher. 2007. Amish Grace: How Forgiveness Transcended Tragedy: San Francisco: Jossey-Bass.

Kraybill, Donald B., Karen M. Johnson-Weiner, and Steven M. Nolt. 2013. The Amish. Baltimore, MD: Johns Hopkins University Press.

Kraybill, Donald. 2001. The Riddle of Amish Culture. Baltimore, MD: John Hopkins University Press.

Kraybill, Donald, and Marc Olshan. 1994. The Amish Struggle with Modernity. Hanover, NH: University Press of New England.

Kreps, George M., Joseph F. Donnermeyer, and Marty W. Kreps. 1997. Quiet Moment in Time: Walnut Creek, OH: Carlisle Press.

Mackall, Joe. 2007. Plain Secrets: An Outsider Among the Amish: Boston, MA: Beacon Press. 
Meyers, Thomas J., and Steven M. Nolt. 2005. An Amish Patchwork: Indiana's Old Orders in the Modern World: Bloomington, IN: Indiana University Press.

Miller, Daniel. 2010. At Home in Hickory Hollow. Winesburg, OH: Legacy Press.

Stevick, Richard A., 2007. Growing Up Amish: The Teenage Years: Baltimore, MD: Johns Hopkins University Press.

Weir, Peter. 1985. Witness.

Wiser, Callie T. 2012. American Experience: The Amish. Public Broadcasting Services (PBS).

Yoder, Joseph W. 1995[1940]. Rosanna of the Amish. Scottdale, PA: Herald Press.

Yoder, Joseph W. 1987. Rosanna's Boys. Harrisonburg, VA: Choice Productions. 